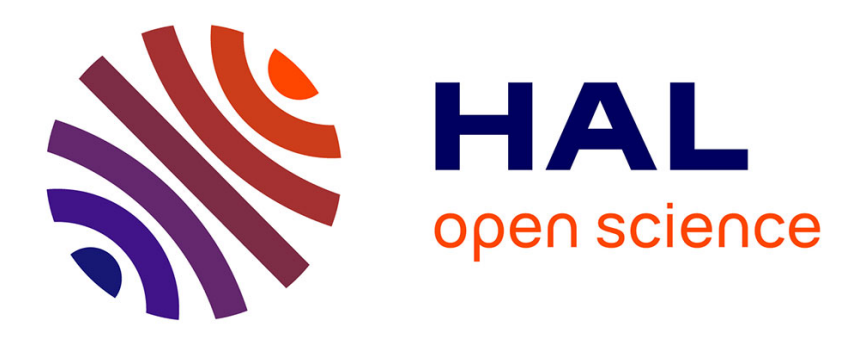

\title{
Valuation of life: genetic models and the making of markets
}

Julie Labatut

\section{To cite this version:}

Julie Labatut. Valuation of life: genetic models and the making of markets. Entreprises et Histoire, 2017, 3 (88), pp.89-102. 10.3917/eh.088.0089 . hal-02617573

\section{HAL Id: hal-02617573 \\ https://hal.inrae.fr/hal-02617573}

Submitted on 25 May 2020

HAL is a multi-disciplinary open access archive for the deposit and dissemination of scientific research documents, whether they are published or not. The documents may come from teaching and research institutions in France or abroad, or from public or private research centers.
L'archive ouverte pluridisciplinaire HAL, est destinée au dépôt et à la diffusion de documents scientifiques de niveau recherche, publiés ou non, émanant des établissements d'enseignement et de recherche français ou étrangers, des laboratoires publics ou privés. 
Capitaliste lui res'entêter à soutenir lle et de fournir « une n'entre aucun grain at vingt-cinq sous par ors même que les prix bas. Mais selon les opos de ces critiques, vant d'être loueur de ste distingué ${ }^{61}$ et a n simple, c'est qu'on conomie de 1300000 loitation, et que cette

tion rationnelle reste ée dans ses applicaux compagnies paride vue de l'efficaciceptation sociale, de lle l'alimentation de nt, l'organisation de tion rationnelle n'est anière de faire qu'un lcul, permettant de ocessus physico-chiqu'ils soient propres onomiques. S'il n'est un cheval son avoine rofits, lui donner à de glucides dont il a tout à fait.

ses in nineteenth-century Europe since the middle

trait et budget ouvrier à Vigna (dir.), La gamelle Nancy, Arbre bleu, 2016,

\title{
VALUATION OF LIFE: GENETIC MODELS AND THE MAKING OF MARKETS
}

\author{
par Julie LABATUT \\ Equipe ODYCÉE (Organisations, DYnamiques des Connaissances \\ et des innovations dans les tErritoires et les filièrEs) \\ UMR AGIR \\ INRA
}

Le développement récent de la génétique et des biotechnologies en élevage a mis en lumière les liens tissés entre les sciences de la vie et des dynamiques de marché. Mettant ces interactions en perspective historique, cet article présente la manière dont la valeur génétique des animaux domestiques a été progressivement construite comme une valeur économique.

\section{INTRODUCTION}

Since the second half of the $13^{\text {th }}$ century, agriculture has been one of the main fields of activity concerned by the development of counting, measuring and "probabilistic reasoning". In the $18^{\text {th }}$ and $19^{\text {th }}$ centuries, "scientific" practices to improve animal genetics emerged, creating the first economic values for hereditary blood products ${ }^{2}$. These practices were attended by a reform discourse, as the following expert from an agricultural journal indicates:

\begin{abstract}
"the one and only question for the farmer is the following [...]: 'What is the most profitable livestock breed [...]?' To answer this question, it is not enough to apply a simple arithmetic rule, and to compare the quantity of food consumed by each batch of animals (in proportion to the meat) with the production of meat; it is indispensable, above all, to know the exact count $[\ldots]$ of each of the two, from the animals' birth and even prior to their birth. While it's easy to say: 'I bred an animal of a race with a symmetrical form, early maturity and excellent quality',
\end{abstract}

${ }^{1}$ M. Power, "Counting, control and calculation: reflections on measuring and management", Human Relations, vol. 57 ,

$n^{\circ}$ 6, June 2004, p. 765-783.

${ }^{2}$ D. Kevles, New Blood, New Fruits: Protections for Breeders and Originators, 1789-1930, Chicago, University of

Chicago Press, 2011, p. 253-269; J. Labatut, F. Aggeri, B. Bibé and N. Girard, "Construire l'animal sélectionnable », Revue d'Anthropologie des Connaissances, vol. $5, \mathrm{n}^{\circ}$ 2, 2011, p. 302-336. 
we're entitled to ask: 'At what cost and after how many failed attempts?"'3.

At the end of the $19^{\text {th }}$ century, the improvement of animal breeds became an increasingly important research are $\mathrm{a}^{4}$ and a realm of action for governments ${ }^{5}$. More recently animal genetics, linking genetic sciences and bioinformatics to economics, has afforded us the opportunity to address research questions of high topicality such as how life and life sciences have become enmeshed in market dynamics ${ }^{6}$, and how to explain the role of technologies in valuation processes $^{7}$. However, unlike plant genetics, livestock genetics has never been patentable, although systems for protecting genetic value have been developed since the $19^{\text {th }}$ century. The market for animal genetic worth existed before the development of genetic theories (it was sometimes considered as "blood value", as the genes were not discovered yet), but has been radically transformed by objectification processes. Statistical methods and scientific instruments for evaluating the genetic potential of animals' performance have contributed greatly to this objectification process.

This paper seeks to explain the links between calculative modes, organisational principles and economic forms in detailing the quantification and valuation process of an intangible good: an animal's genetic worth. The analysis focuses on instruments of calculation such as genetic indexes, an interna- tional reference allowing comparison of cattle's genetic performance among farms, regions and more recently countries where scientific models of animal breeding have been developed regardless of the environ mental effects (feeding, climate, etc.) Designed by geneticists from public research institutes, genetic indexes rely on the rational myth of maximising production per unit and the breaking down of performance into subunits that can be optimised separately. They represent animals' genetic value on various criteria: milk yield, milk quality, carcass yield, udder morphology, etc. This analysis highlights the construction of specific conventions of quantification and valuation principles, and how these conventions allow the development of specific market objects and forms.

To unfold these processes of valuation. this paper draws on concepts from economic sociology and more specifically studies in sociology of accounting. It argues that studying accounting processes in the broad sense, and the specific role of mediating instruments ${ }^{8}$ such as genetic indexes linking science and the construction of an economic value for animals' semen, furthers our understanding of the making of markets through the analysis of detailed processes of quantification, evaluation and calculation, and the role of scientific models and practices in these processes. The notion of "mediating instruments" is indeed "a fruitful way of

${ }^{3} \mathrm{C}$. Gomart, « Le bétail de la ferme », Journal d'agriculture pratique et de jardinage, vol. $3, \mathrm{n}^{\circ} 1,20$ novembre 1850 p. 64, quoted by T. Depecker, Ia loi des tables. Quantification du besoin alimentaire et réforme des novembre 1850 $X I X^{2}-X X^{2}$ siecles, PhD thesis in sociology, EHESS, 2014

${ }^{4}$ B. A. Kimmelman, "The American Breeders" Association: Genetics and Eugenics in an Agricultural Context, 1903 13", Social studies of science, vol, 13, $\mathrm{n}^{\circ} 2$, May 1983, p. 163-204.

5 J.-L. Mayaud, "La "belle vache" dans la France des concours agricoles du XIX" siècle ", Cahiers d'Histoire, vol, 42 "1 3-4, 1997, p. 521- 541; J, Labatut et al., « Construire 1'animal sélectionnable », art. cit.

${ }^{6} \mathrm{~S}$. Helmreich, "Species of biocapital", Science as culture, vol. 17, n० 4, December 2008, p. 463-478.

7 J. Dewey, "Theory of valuation", in International Encyclopedia of Unified Science, vol. 2, n 4, Chicago, The University of Chicago Press, $1939, \mathrm{p}, 1-67 ; \mathrm{H}$. Joas, The genesis of values, Cambridge, Polity Press and Chicago, The this volume, the presentation written by A Bey, La formation des valeurs, Paris, La Découverte, 2011. See also, within tion des valeurs », p. 5-64. (P. Miller and T, O'Leary,

${ }^{8}$ P. Miller and T: O'Leary, "Mediating instruments and making markets: Capital budgeting, science and the econonv", Accounting, Organizations and Society, vol. 32, $\mathrm{n}^{\circ} 7-8$, October-November 2007, p. 701-734. 
mparison of catamong farms, countries where breeding have of the environclimate, etc.). public research $y$ on the rational on per unit and nance into subeparately. They lue on various uality, carcass . This analysis f specific convaluation prinions allow the et objects and

of valuation, rom economic lly studies in Ies that studybroad sense, iating instrus linking scian economic rs our underkets through s of quantifiion, and the practices in f "mediating tful way of

lovembre 1850 , onduites de vie

Context, 1903-

istoire, vol. 42,

Chicago, The Chicago, The ee also, within ey et la formahe economy", examining the ways in which science and the economy come to be linked, offering both ways of representing and intervening"9. As Pierre Lascoumes and Patrick Le Galès argue, focusing on instruments allows one "to move beyond functionalist approaches" in deconstructing action through instruments, as they are not "tools with perfect axiological neutrality, equally available; on the contrary, they are bearers of values, fuelled by one interpretation of the social and by precise notions of the mode of regulation envisaged" 10 .

To this end, we have to explore the relations between the order of calculation and the order of values (aesthetic, moral, economic, etc. $)^{11}$. Max Weber and, more recently, Herbert Simon advocated the distinction between calculation and values, between techniques and the economy ${ }^{12}$, considering that the genesis of values is extrinsic to action and rationality, which determine the more efficient means to reach given ends. They thus oppose values and techniques, as in the realm of animals and plants genetics, where geneticists used to consider that the genetic models they design were neutral and universal, and were only means that could be used to any type of ends. This paper develops a different historical analysis explaining the constitution and establishment of both technologies and institutions that allow economic valuation. It describes the development of a scientific regime of calculation ${ }^{13}$ of live${ }^{9}$ Ibid.

${ }^{10}$ P. Lascoumes and P. Le Galès, "Introduction: Understanding Public Policy through Its Instruments: From the Nature
of Instruments to the Sociology of Public Policy Instrumes Administration, and Sociology of Public Policy Instrumentation", Governance: An International Journal of Policy, ${ }^{11}$ See A. Bistration, and Institutions, vol. 20, $\mathrm{n}^{\circ} 1$, January 2007, p. 1-21.

${ }^{12}$ Ibid.

tet al, « Cen a

13 A

European electronic P. Miller and R. Samiolo, "Accounting for Economic Sociology", Economic sociology. The ${ }^{14}$ Foll electronic newsletter, vol. 10, $\mathrm{n}^{\circ} 1$, November 2008, p. 3-8.

which behaviours, Ķalişkan and Michel Callon, we use "the term 'economisation' to denote the processes through K. Çalişkan and M. Callon "Economizations and, more generally, objects are constituted as being "economic": : see Society, vol. 39, $\mathrm{n}^{\circ}$ 1, February 2010, p. 1-32. part 2: a research programme for the study of markets", Economy and 15 N

Cambridge University Press, 1986. ${ }^{16}$ D. Kevles, New Blood, New Fruits, op. cit. stock, and the role of the State in structuring this regime, and emphasises the long history of the economisation of animals and their genetic worth.

\section{ECONOMISATION OF LIFE: A LONG HISTORY}

The historical analysis of the economisation $^{14}$ of living animals for their genetic value reveals two unexpected aspects of the links between nature, science and economy. While the economisation of life (both human (s a subject of increasing picality, partly due to the development of

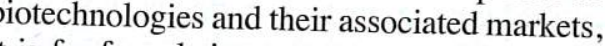
from being a recent phenomenon. It developed long before scientific theories on processes allowed the "objective" (the first economic value given to animals for genetic worth, i.e. their potential of bas defined as a "good cept of "genes" was ofrspring (as the conidentified as early as the end of the $18^{\text {th }}$ century, before the development of any scientific theory on genetic laws (Mendel: mid-19 $9^{\text {th }}$ century $)^{16}$. Agricultural innovators in $17^{\text {th }}$. and $18^{\text {th }}$-century England initiated the development of practices and methods to judge animals not only on their direct quality for . 
production, but also on their capacity to transmit this quality to their offspring (potential for reproduction and not only for production). The objective was not only to assess for actual performance but also for future performance and for an immaterial capacity. The question was then: how to assess for a potential? How to measure the unknown, how to measure the future? This new objective implied the need to change common farming practices: most farmers used to sell their best stock to the butcher, and used their poorest for breeding ${ }^{17}$.

Robert Bakewell (1725-1795), a farmer and agriculturist from Leicestershire, is usually regarded as the first to have successfully applied precise methods aimed at producing early maturing meat-producing animals, which would "transmit these qualities with increased certainty"18. The emergence of such practices, one century before any scientific development, already shed light on the development of strategies, practices and discourses to render nature more "objective". Historians explain how Bakewell and his colleagues were seeking precision, certainty and assessment in their breeding practices ${ }^{19}$, illustrating what other authors called the "metrological mood" which started in the $13^{\text {th }}$ century ${ }^{20}$. Those discourses were also used to fuel reform campaigns, as agricultural schools and professional journals relentlessly spread the idea that the purpose of agriculture was to breed not the most beautiful animals, but the most profitable ones ${ }^{21}$.
In order to evaluate animals' capacities to transmit their qualities, "scientific"22 agriculturists developed tools, devices, systems of relations and market rules between farmers. For example, due to the limited surface area of the land at Dishley, where Robert Bakewell had his farm, as well as the limited numbers of stock he could maintain, he developed a system of letting out his sires and their offspring for the season to other farmers. Thanks to this system, he could judge the quality of his sires under various environments: "he was thus enabled to study their respective performances in other herds and flocks, and under different environmental conditions"23. This system was an early version of the so-called now "progeny-testing principle", which would be the only method for evaluating animals' genetic worth until 2009 , and the core principle of the scientific regime of calculation developed in the 1950 s, as explained later in the paper. The practices and principles linked to this regime were found first in farming practices rather than in the scientific domain. At first, animals were tested on very few numbers of farms, as mating rams and sires had to be transported to those farms during mating periods.

Progeny testing relies on the measurement or observation of the performance of offspring in various environments to evaluate the genetic value of the sire or ram. The process of progeny testing used to take several years (until enough offspring could start producing milk or meat) and was very costly (as we will see later in the paper, at the begin${ }^{17}$ C. T. Leavitt, "Attempts to improve cattle breeds in the United States, 1790-1860", Agricultural History, vol. 7 ,
April 1933, p. 51-67.

${ }^{18}$ H. C. Pawson, Robert Bakewell, pioneer livestock breeder, London, Crosby Lockwood, 1957.

${ }^{19}$ Ibid;; see also N. Russell, Like Engend'ring Like, op. cit.

${ }^{20} \mathrm{~T}$. M. Porter, Trust in numbers: the purswit of objectivity in science and public life, Princeton, Princeton University Press, 1995; M. Power, "Counting, control and calculation", art. cit.

${ }^{21}$ T. Depecker, La loi des tables, op. cit.

${ }^{22}$ Here, defined as agriculturist developing scientific logics of trials and errors, experiments, looking for producing knowledge on animals.

${ }^{23}$ T. Depecker, La loi des tables, op, cit. 
animals' capacities to "scientific"22 agriculdevices, systems of les between farmers. limited surface area ley, where Robert as well as the limited could maintain, he letting out his sires the season to other is system, he could sires under various hus enabled to study lances in other herds ifferent environmensystem was an early now "progeny-testwould be the only imals' genetic worth principle of the scition developed in the er in the paper. The linked to this regime ning practices rather ain. At first, animals numbers of farms, as ad to be transported ating periods.

es on the measurethe performance of ronments to evaluate sire or ram. The proused to take several ring could start prowas very costly (as paper, at the begin-

icultural History, vol. 7 , 957.

ton, Princeton University

ts, looking for producing ning of the $21^{\text {st }}$ century, testing a bull used to cost 40000 to 50000 euros and only one in ten had a good enough genetic value to be kept for commercial use). This principle allowed breeders to produce and sell not only animals but also a genetic potential. The first methods of organising the evaluation of animals' genetic worth were closely related to the control of the market for breeding animals. To control this market, Bakewell established the Dishley Society in 1783 in order to ensure the monopoly of the breeder members of the society. Most of the rules in this breeders' society were turned towards defining the prices and the scale of exchanges of animals on the market:

\section{Rule 4: "No member shall let a ram for less than ten guineas"}

Rule 6: "No member shall let a ram to any one who lets or sells his rams at fairs or markets"

Rule 8: "Mr. Bakewell engages not to let any ram for less than fifty guineas to any person residing within one hundred miles from Dishley"

Rule 9: "No member shall let a ram to any person residing within thirty miles from Leicester, and not being a member of the Society, who shall have hired a ram of Mr. Bakewell during the preceding season" 24 .

With these rules to frame the breeding animal market and almost set a monopoly, these pioneers were trying to protect the return for their outlay of time, money and care in improving their flocks ${ }^{25}$. These first elements indicate the historical relationship between breeding techniques and practices and market structures.

\section{THE EMERGENCE OF A SCIENTIFIC REGIME OF CALCULATION}

\section{The need for objectivity to govern animals and breeders}

At the end of the $19^{\text {th }}$ century, governments started to intervene in the organisation of animal breeding activities by funding and controlling animal fairs and competitions. "The development of county fairs, or, as they were often called, the cattle shows, enabled farmers to compare the quality of their cattle with that of their neighbours, and by appealing to their pride, encouraged them to have livestock of at least equally good quality"26. For example, in France, livestock improvement started to become a government objective. Between 1880 and 1940, the State controlled the procedures of livestock competitions, which it used to award bonuses to the best breeders ${ }^{27}$. Its aim was to strip the elites of their predominant role in the evaluation of animals. Through these incentives and practices of control, the State started to be aware of the limits and misappropriation of existing instruments for organising breeding activities (Herd Books - books used to register the genealogies of each animal of a specific breed, created in the $19^{\text {th }}$ century, where breeders' associations defined breeding standards and recorded animals' pedigrees; and animal competitions). Animal competitions were considered to put more emphasis on the social status of breeders than on the efficiency and quality of their breeding practices. They moreover proved to be inefficient, for the same farmers' elite and prominent breeders were often rewarded, while the quality of

\footnotetext{
${ }^{24}$ H. C. Pawson, Robert Bakewell, op. cit.

${ }^{25}$ Ibid.

${ }^{26}$ C. T. Leavitt, "Attempts to improve cattle breeds in the United States", art. cit.

${ }^{27}$ J.-L. Mayaud, « La "belle vache" dans la France des concours agricoles », art. cit.
} 
the animals was sometimes secondary. The principle of visual evaluation thus revealed its limits on the "over-the-counter" animal market. Indeed, such a learning process soon reached its limits: sight (visual evaluation), feel, touch and weight up are not trials of universal truth and allow only limited access to the knowledge of things and behaviours ${ }^{28}$.

Livestock production and animal breeding became an object of government in several countries, and the spirit of objectivity pervaded this domain of practices. In 1906, in his book The Breeding Industry, its Value to the Country, and its Needs, Walter Heape advocated for the "right application of Science to the industry" of animal breeding in the United States, convinced as he was that the breeding industry was "the greatest industry to which Science has never yet been applied"29. The challenge for the country was to beat other countries in the competition for the best animals: "the English breeder has always enjoyed supremacy over all foreign competitors, and he still holds the first position in the world, but how long will it continue to be so?"30. For this scientist. "the means to be employed in combating such competition is not repression, as some suggest, it is by increasing the stimulus which governs the success of the industry that our competitors will be mastered, and, as in agriculture, so in breeding, it is science that must do the work" (emphasis added).
This book illustrates very well the difficulties in the objectification process of breeding animals, which was considered until then as an "art" 31 . The author gives some arguments to explain why Science had neglected breeding activities until then:

"there are doubtless many reasons for this; the problems are so difficult, breeding is such a subtle matter, the conditions are so varied, the results so contradictory, it seems so hopeless to attempt to grapple with the problems presented, and indeed they are themselves so little understood" 32 .

The opposition between scientific knowledge and empirical knowledge also seemed to be a limit to the objectification of breeding practices and the development of "breeding science":

"In the same way, the man of science is apt to overlook the immense value of the store of knowledge which the breeder has at his disposal, he is apt to consider it of very little use to him. He finds difficulty in obtaining a satisfactory account of the breeder's knowledge, he finds his methods governed by beliefs for which no adequate reason can be given" 33 .

Despite this broad process of objectification, "science" and "art" will always coexist in breeding practices and in animal competitions, as several authors have shown ${ }^{34}$. ${ }^{28}$ A. Hatchuel, «Les marchés à prescripteurs », in A. Jacob and H. Vérin (eds.), L'inscription sociale du marche, Paris,
LiHarmattan, 1995. ${ }^{29} \mathrm{~W}$. Heape, The Breeding Industry. Its Value to the Country, and its Needs, Cambridge, Cambridge University Press,
1906 .

30 lbid.

${ }^{31}$ W. Heape, The Breeding Industry, op. cit.

${ }^{32}$ Ibid, p. 20.

${ }^{33}$ Ibid, p. 23.

${ }^{34}$ A. Procoli, « Le temps et la construction du regard sur l'animai de rente. Ethnographie des pratiques et récits des éleveurs bretons », Cahiers d'Économie et Sociologie Rurales, $\mathrm{n}^{\circ}$ 72, 2004, p. 92-113; C. Grasseni, Developing skill, deyeloping vision: practices' of locality at the foot of the Alps, New York, Berghahn Books, 2009; J. Labatut, F. Aggeri, J,-M. Astruc, B. Bibé and N. Girard, "The active role of instruments in articulating knowing and knowledge", The
Learning Organization, vol, 16, n' 5, 2009, p. 371-385. 
es very well the diffiation process of breeds considered until then hor gives some arguScience had neglected 1 then:

ss many reasons for are so difficult, breedmatter, the conditions sults so contradictory, to attempt to grapple oresented, and indeed res so little under-

yeen scientific knowlowledge also seemed tification of breeding opment of "breeding

he man of science is mmense value of the vhich the breeder has apt to consider it of . He finds difficulty ictory account of the , he finds his metheliefs for which no be given" 33 .

ocess of objectificawill always coexist 1 in animal competihave shown ${ }^{34}$.

sociale du marché, Paris, abridge University Press,

is pratiques et récits des asseni, Developing skill, 99; J. Labatut, F. Aggeri, ig and knowledge", The

\section{The development of quantitative genetics theories as a probabilistic model for allowing 'objective' calculation of life}

These historical practices of progeny-testing and genetic markets nevertheless remained disconnected from later scientific developments (Mendel's theory in the mid$19^{\text {th }}$ century) until the beginning of the $20^{\text {th }}$ century and the development of statistical theories ${ }^{35}$. In the early $20^{\text {th }}$ century, various scientists (biologists and mathematicians), some of them rediscovering Mendelism, started to work on theories and methods to explain and predict the genetic evolution of populations, although they were opposed by two competing paradigms of hereditary science biometry and Mendelism, leading to a controversy, largely studied by science studies scholars $^{36}$. The development of models for genetic evolution based on statistical techniques (correlation, regression) allowed for theoretical prediction of the future of living populations.

In 1918, Ronald Fisher wrote an article identified as the starting point for quantitative genetics ${ }^{37}$. When this discipline was introduced and developed in the realm of animal breeding, it led to an important change in the scale of the management of animal breeding activities. The focus was no longer on the individual (the best animal), but on the whole population $^{38}$. The paradigm underpinning this discipline was "statistic and relative" 39 . Quantitative genetics is based on the analysis of hereditary transmission of quantitative characters, characters that are measurable thanks to specific instruments (such as milk recording).

Quantitative genetics made it possible to get rid of the effects of environment and to evaluate the effects of genes in the performance of an individual. Indeed, the latter was defined by geneticists through the following simplified model, as indicated in every introductory course of quantitative genetics.

$$
\mathrm{P}=\mu+\mathrm{G}+\mathrm{E}
$$

In this formula, $\mathbf{P}$ is the performance, $\mu$ the mean of the phenotypic values of a population, $\mathrm{G}$ the variance due to the effects of the genotype, and $\mathrm{E}$ the variance due to the effects of the environment (age of the animal, feeding, climate, etc.). P can be measured (for example through milk recording), but G and $\mathrm{E}$ are unknown. This model estimates variance of $\mathrm{G}$ and $\mathrm{E}$ on a large set of data (an animal population) to distinguish their respective effect on P. Quantitative genetics thus helped to create the phenotype and the genotype of an individual as operational concepts in terms of measurement. The phenotype is translated in terms of "phenotypic value", indicating the "result of a measure" upon the individual ${ }^{40}$, such as milk recording, or the analysis of milk content in terms of fat and protein. The genotype is translated in terms of "genetic value", and is attached to a sire, expressing the "mean value of its off-

${ }^{35}$ On the transition from the art of breeding to science in the Netherlands see B. Theunissen, "Breeding for nobility or for production? Cultures of dairy cattle breeding in the Netherlands, 1945-1995", Isis, vol. 103, n 2, June 2012, p. 278309

${ }^{36}$ R. Olby, "The Dimensions of Scientific Controversy: The Biometric-Mendelian Debate", The British Journal for the History of Science, vol. 22, n 3, September 1989, p. 299-320; C. Bonneuil, "Mendelism, plant breeding and experimental cultures: agriculture and the development of genetics in France", Journal of the History of Biology, vol. 39, $n^{\circ} 2$, July 2006, p. 281-308.

${ }^{37}$ L. Ollivier, « Histoire de la génétique quantitative », Ethnozootechnie, n 63, 1999, p. 61-68.

${ }^{38}$ Ibid.

39 J. Mallard, « Les bases de la génétique quantitative. Populations et variabilité », Productions Animales, hors série, 1992, p. 55-60.

${ }^{40}$ L. Ollivier, « Histoire de la génétique quantitative », art. cit. 
spring, assumed to be an infinite number and located in specific, controlled environmental conditions $" 41$

\section{From a biological model to an organisational model: progeny-testing at a large scale}

Despite these growing genetic theories and scientific disciplines. in France scientific progress remained disconnected from the economic field of breeding until the mid$20^{\text {th }}$ century. Christophe Bonneuil already emphasised this separation in the field of plant breeding:

"prior to 1944, the government's efforts to 'modernise' national agriculture were modest, which explains the limited investments in agricultural research before 1945 (in sharp contrast to its steady expansion in the USA at the same time). Moreover, agricultural higher education (under the authority of the Ministry of Agriculture) and universities (Ministry of Education) were poorly interconnected in the first half of the twentieth century, which severely impeded cross-fertilisation between academic biology and agricultural research" 42 .

This quantitative genetics model and the data needed to evaluate $G$ while $E$ is unknown imply a specific organisational structure for the application of quantitative genetic theories in the animal breeding industry. Quantitative genetics implies the observation and measurement of the performance of a large number of individuals in order to process statistical models. In our study this relied on the extension of milk recording syndicates which provided objectified measures of animals' performance since the beginning of the $20^{\text {th }}$ century (the first milk recording syndicate was formed in 1908 in Pays de Caux, France ${ }^{43}$ ).

After World War II and the State's wish to improve livestock productivity, scientists from public research, considering that "sperm is not from the right or the left wing. it is good or bad" "44 designed national breeding programmes involving networks of farms participating in performance recording services. In the same period, progress in reproduction science was implemented on farms with the spread of artificial insemination on a large scale. The development of artificial insemination - thanks to which the reproductive capacity of a single animal could be multiplied, a new market opened up, and farming practices homogenised - corresponded to two principles of genetic models: the multiplication of offspring on a large number of farms to produce more performance data, and the elimination of the effects of the environment. Thus, little by little, breeding programmes involved services providing the following: the recording of performance (milk quantity, milk quality, growth rate, etc.); breeders' cooperatives rearing sires and testing them on the animal population: $R \& D$ organisation calculating genetic values; artificial insemination services distributing sperm straws and the genetic gain produced. The genetic merit of a bull - meaning its capacity to produce offspring with increased performances - is not a tangible property, but it results from an experimental setting accounting statistically for this capacity. The larger the setting. the greater the reliability of the statistical account

41 Ibid.

${ }^{42} \mathrm{C}$. Bonneuil, "Mendelism, plant breeding and experimental cuitures", art. cit.

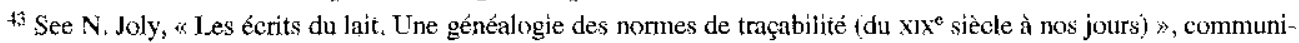
cation aux journées d'étude Tracer Auditer les denrées alimentaires organisées par l'INRA (RiTME et LISTO), 8-9 septembre 2011 .

$\$ 4$ Jacques Poly, quoted by B. Vissac, Les vaches de la République, Saisons el ratsons d'un chercheut citoyen, Paris, INRA, 2002 .

Evaluating $\mathrm{G}$ in this model still principle of progeny testing - me mating the value of a sire on the $p$ of its offspring. This had already oped by Bakewell and some leagues, but with the developmen tative genetics and official $p$ recording methods it acquired a and objective basis in terms of measurement (milk and meat evaluated through official and recording services, genetic eva culated by an independent and tute). Practices changed accor development of large-scale meas calculation of animals" value b measurement and accountabili imagined long before, arguing a nologically deterministic view tices ${ }^{45}$

This new regime of calcula huge quantity of data on at applied on a large scale, and $b$ the increasing calculative cap mation technologies and con second half of the $20^{\text {th }}$ century. calculative capacities of hum application of these statistic "real" livestock populations numbers of individual animals limited. From the 1950s onw the INRA (the National Agronomic Research) was a development of calculative quantitative genetics. The information technologies computers helped to incre capacities and to develop qu ics theories applied to real tions. The development of it nologies and computers in

45 M. Power, "Counting, conirol an 45 P.É Mounier-Kuhn, L'informan . B. Maris, PUP, 2010.

4 G. Steier, « Lá gestion des pop s. Stennées $\$$, Product

4 Vissac, Les vaclies de la Rép 
extension of milk provided objectiperformance since century (the first as formed in 1908

the State's wish to ictivity, scientists considering that at or the left wing, ed national breednetworks of farms ce recording serprogress in reproemented on farms insemination on a ment of artificial hich the reproducmal could be muled up, and farming corresponded to nodels: the multilarge number of eerformance data, effects of the envitle, breeding proproviding the folerformance (milk rowth rate, etc.); ing sires and testpopulation; R\&D netic values; artiices distributing tic gain produced. ull - meaning its ng with increased gible property, but erimental setting this capacity. The er the reliability of

10s jours) », communiRiTME et LISTO), 8-9 ercheur citoyen, Paris,
Evaluating $\mathrm{G}$ in this model still lies on the principle of progeny testing - meaning estimating the value of a sire on the performance of its offspring. This had already been developed by Bakewell and some of his colleagues, but with the development of quantitative genetics and official performance recording methods it acquired a theoretical and objective basis in terms of performance measurement (milk and meat production evaluated through official and independent recording services, genetic evaluations calculated by an independent and public institute). Practices changed according to the development of large-scale measurement and calculation of animals' value, but the idea of measurement and accountability had been imagined long before, arguing against a technologically deterministic view of such practices $^{45}$.

This new regime of calculation needed a huge quantity of data on animals to be applied on a large scale, and benefited from the increasing calculative capacity of information technologies and computers in the second half of the $20^{\text {th }}$ century. With only the calculative capacities of human beings, the application of these statistical models to "real" livestock populations and very high numbers of individual animals had been very limited. From the 1950s onwards, in France, the INRA (the National Institute for Agronomic Research) was a pioneer in the development of calculative capacities for quantitative genetics. The development of information technologies and calculating computers helped to increase calculative capacities and to develop quantitative genetics theories applied to real animal populations. The development of information technologies and computers in France was sup- ported by the 1966 Plan Calcul, a governmental plan launched by De Gaulle to ensure France's independence from other countries in terms of big computers and calculation capacities ${ }^{46}$. The Department of Animal Genetics was the first research department at the INRA to use the most powerful computers at that time ${ }^{47}$. In 1962, the INRA recruited an engineer from IBM to develop the Institute's calculative capacities for animal genetic evaluations. Between 1962 and 1966, experiments and simulations were conducted on small samples of bovine populations, which enabled the INRA to design prototypes for calculating the genetic indexes of animals for milk production. Genetic indexes gave a numeric value that estimated the genetic potential of these animals according to their milk production. Scientific theories of quantitative genetics, along with performance recording and artificial insemination, thus allowed the Institute to calculate the future of animal genetic performances, to predict results, to adopt planning logics, and to get rid of the "trial and error" practices of traditional breeders. Through this paradigmatic change based on a probabilistic logic ${ }^{48}$, it became possible to predict animals' performance. The managerial project of this emerging regime of calculation promoted by the State was about objectifying not only knowledge, but also relations between farmers (and in fine the market). It was about replacing traditional relations based on status and social rank by relations of objectivity: the trading of animals between farmers was to be based on objective values and not on reputation. This managerial project was to ensure that measurement was no longer influenced by judgement based on "living experience" of the animals' quality, and that exchanges

\footnotetext{
${ }^{45} \mathrm{M}$. Power, "Counting, control and calculation", art. cit.

${ }^{46}$ P.-É. Mounier-Kuhn, L'informatique en France de la Seconde Guerre mondiale au Plan Calcul. L'émergence d'une science, Paris, PUPS, 2010.

${ }^{47}$ G. Steier, « La gestion des populations. La circulation de l'information génétique et sa structuration sous forme d'une base de données ", Productions Animales, hors série, 1992, p. 223-227.

${ }^{48}$ B. Vissac, Les vaches de la République, op. cit.
} 
were no longer dependent on the status of participants ${ }^{49}$.

\section{The 1966 Breeding Law: calculating animals as a public service}

Translating this scientific model based on statistics and quantitative genetics into a regime of calculation linking science to the breeding industry implied the development of a heavy and costly setting. In 1966, the French State, wishing to ensure the country's food autonomy, decided to work with INRA geneticists ${ }^{50}$ to promote and intervene in the development of a national, public and cooperative system for large-scale animal calculation and breeding, under the regulation of the "Breeding Law". This policy was foremost dedicated to species for which progeny testing was the most costly and difficult to implement on a private basis, especially in France where farms are small compared to other countries: species with a long generation interval and a low reproductive rate, i.e. cattle, sheep and goats. The genetic merit of animals started to become an explicit objective of government, through its calculation, management and diffusion.

In this regime, cooperation was organised to intensively produce collective and objectified knowledge on animals. The regime was based on the organisation and planning of the production of knowledge and on collaboration with the government, aimed at ensuring social justice. In other words, the genetic gain produced by national breeding pro. grammes was to benefit the entire breed and all farmers, as the government funded data processing and scientists' research. This regime relied on a complex cooperation between scientists, breeding organisations, farmers, and the State to organise progeny testing of breeding animals on a wider scale and thus overcome the limitations of "traditional" breeding practices. The idea was thus to democratise spheres previously dominated by certain professional elites ${ }^{51}$.

The Breeding Law thus framed the organisation of a scientific and economic setting for genetic selection ${ }^{52}$. The State disciplined, prescribed and managed the production of genetic gain on animals. It entrusted the INRA with the mission of calculating the genetic value of all the animals involved in French breeding programmes, and even gave it a monopoly in this respect. The government also regulated and controlled the genetic selection market by imposing norms and agreements on animals' genetic quality, and granted a territorial monopoly to breeding companies. In return, companies had to provide genetic gain and sperm straws to every farmer in their area, even if their farm was isolated (for example in mountainous areas), insofar as artificial insemination was a public service. This organisation was based on the development of strong ties between the profession, the State, and public research. The UNCEIA (the union of breeding and artificial insemination co-operatives) worked hand in hand with INRA scientists on common research programmes, through what

\footnotetext{
${ }^{49}$ N. Rose, "Governing by numbers; Figuring out democracy", Accounting, Organizations and Society, vol. 16, no 7 ,
1991 , p. 673-692.

${ }^{5}$ As Vissac showed, in 1965 Edgar Faure, then Minister of Agriculture, appealed to scientists and particulariy Jacques Poly, founder and director of INRA:s Department of Animal Genetics, to design the French genetics system. See B. Vissac, Les vaches de la République, op, cit.

5l M. Power, "Counting, control and calculation", art, cit.

52 This regime referred to the Fordist regime discussed by Bonneuil et al., concerning plant variety selection based on expertise, science-based action, and the design of decision support tools. See C. Bonneuil, E. Demeulenaere, F. Thomas, P.-B. Joly, G, Allaire and I. Goldringer, « Innover autrement '? La recherche face à l'avènement d' un nouyeau régime de production et de régufation des savoirs en génétique végétale \%, Dossiers de l'Environnement de
} l'I $\backslash R A, n^{\circ} 30,2006, \mathrm{p} .29-53$.

Franck Aggeri and Armand $\mathrm{H}$ called a neo-corporative ordes management system" between and the State ${ }^{54}$ was a distinct the government of agriculture and 1980 .

\section{A national system fo producing and proce animal genetic data}

The institutionalisation of tem for "calculating animals" eral steps, which linked scien tional and economic dimens step of the calculation process the genetic worth of animals opment of a system for meas performances. $\mathrm{P}$ (phenotype) through performance measu recording of thousands Organising the objective mea national level relied for dairy development of milk recordi

Milk recording groups $/ u$ ed since the beginning of the had remained relatively lim the number of animals reco Breeding Law triggered the opment of milk recording $s$ 2.6 million cows have been represents $70,3 \%$ of all Frer With this milk recording ser milk recording organisatic externalise and objectif recording. These professio could have various status unions, co-ops or services Chambers of Agricult d'Agriculture]) and were

${ }^{53} \mathrm{P}$. Aggeri and A. Hatchuel, «O critique des rapports sciences soi ${ }^{54}$ P. Muller, « Lanalyse cognitive françalse de science polititume, $v$ ${ }^{5}$ Chiffies dés 2015 , Production de l'élevage, 2015.

56 M. Callon and F. Muniess, octobre-décembre 2003 , p. 1892 
oreeding protire breed and t funded data search. This cooperation organisations, nise progeny a wider scale ons of "tradiidea was thus ly dominated

framed the conomic setState discithe producIt entrusted lculating the involved in ad even gave The governed the genetnorms and quality, and to breeding had to prows to every ir farm was nous areas), was a public ased on the en the prosearch. The nd artificial red hand in common igh what

vol. $16, \mathrm{n}^{\circ} 7$ d particularly netics system.

tion based on emeulenaere, ent d'un nouonnement de
Franck Aggeri and Armand Hatchuel have called a neo-corporative order ${ }^{53}$. This "comanagement system" between the profession and the State ${ }^{54}$ was a distinctive feature of the government of agriculture between 1960 and 1980 .

\section{A national system for producing and processing animal genetic data}

The institutionalisation of a national system for "calculating animals" involved several steps, which linked scientific, organisational and economic dimensions. The first step of the calculation process for evaluating the genetic worth of animals was the development of a system for measuring observed performances. $\mathrm{P}$ (phenotype) became known through performance measurement and the recording of thousands of offspring. Organising the objective measurement of $\mathrm{P}$ at national level relied for dairy livestock on the development of milk recording services.

Milk recording groups/unions had existed since the beginning of the $20^{\text {th }}$ century, but had remained relatively limited in terms of the number of animals recorded. The 1966 Breeding Law triggered the national development of milk recording services. To date, 2,6 million cows have been recorded, which represents $70,3 \%$ of all French dairy cows ${ }^{55}$. With this milk recording service, new actors, milk recording organisations, emerged to externalise and objectify performance recording. These professional organisations could have various statuses (associations, unions, co-ops or services integrated within Chambers of Agriculture [Chambres d'Agriculture]) and were independent of breed societies (UPRAs) and breeding companies, but were framed by a territorial monopoly granted by the State. This regime was characterised by the diffusion of a production model designed to maximise efficiency, that is, a uniformity of breeding practices and systems, combined with the emergence of production standards such as fat and protein levels in milk, and bacteriological standards in the industrial sector.

Once $P$ was obtained on a large number of individuals, in a variety of environments, E could be evaluated by measuring intra- and inter-herd/flock variances. In order to process this enormous amount of data on animals, INRA geneticists organised the development of a national system of genetic data, thus creating a centre of calculation ${ }^{56}$, the CTIG (Centre de Traitement de l'Information Génétique) in Jouy-en-Josas (within the INRA animal genetics department), on which the commensuration of animals' performances relied.

This calculation centre processed data resulting from the measurement of animals' performances for the production of genetic indexes, according to specific data standards. The codification of evaluation procedures in different regions allowed for a collective management of genetic data at the level of each breed and nationally. This codification standardised evaluation procedures and permitted the comparison of animals' performances on a common metric - a comparison that was both time-based (historical) and spatial (comparison between all controlled farms).

The genetic model allowing for the calculation of animals' genetic worth also

${ }^{53} \mathrm{~F}$. Aggeri and A. Hatchuel, « Ordres socio-économiques et polarisation de la recherche dans l'agriculture : pour une critique des rapports science/société », Sociologie du travail, vol. 45, janvier-mars 2003, p. 113-133.

${ }^{54} \mathrm{P}$. Muller, « L'analyse cognitive des politiques publiques : vers une sociologie politique de l'action publique », Revue française de science politique, vol. $50, \mathrm{n}^{\circ} 2$, avril 2000, p. 189-207. ${ }^{55}$ Chiffres clés 2015. Productions bovines Lait et viande, Paris, GEB-Institut de l'élevage et Confédération nationale
de l'élevage, 2015. ${ }^{56}$ M. Callon and F. Muniesa, « Les marchés économiques comme dispositifs collectifs de calcul », Réseaux, $\mathrm{n}^{\circ} 122$,
octobre-décembre 2003, p. 189-233. 
defined the economic and accounting structure of breeding companies, based on a public, cooperative and mutualist form of economy. The principle of progeny testing, needed to calculate genetic indexes, implied a huge investment on numerous animals for at least five years, due to long generation intervals in cattle and low prolificacy. Breeding companies had contracts with farmers. from whom they bought bulls that they considered to have the greatest potential, based on their pedigree information. For example, they would buy ten bulls a year, make them produce semen for testing, then keep them for four or five years in "lay-off" stations, while sufficient numbers of their offspring were produced and their performance was measured. This process of progeny testing used to cost about 40000 to 50000 Euros per bull. After the progeny-testing period, bulls would be given their genetic indexes and usually only one in ten would be considered good enough in terms of genetic merit to be kept for commercial purposes. Breeding companies would then have to sell 400000 to 500000 Euros of indexed semen (sperm straw) per bull to ensure their return on investment, on a 5-year turnover. This economic model had consequences on markét culture, and participated in the development of what geneticists call the "star system". Once a bull obtained really good genetic indexes, it quickly became a "star" and was over-sold. sometimes leading to inbreeding problems in the industry. Because of this long-term investment, and uncertain returns, breeding companies have kept a cooperative status until now. No private company in France invested in such a costly and uncertain market.

The implementation of this genetic and organisational model for calculating animals: genetic value radically transformed the nature of animal genetics markets. It trig- gered a dematerialisation of the exchanged objects: from breeding animals to the cre ation of a service of artificial insemination where the exchanged good is indexed semen. It also anonymised the market: whereas the market had previously been governed by the reputation of a few farmers known for their competencies in producing high-value animals (what Joel M. Podolny and Marya HillPopper would call a transcendent conception of value ${ }^{57}$ ), under the scientific regime of calculation, "genetic indexes" are the reference value on the market and no longer the name of the farmer who produced the animal (what Podolny and Hill-Popper would call a hedonist conception of value ${ }^{58}$ ). Genetic indexes and artificial insemination also allowed for a radical change of the market scale: animal semen could be sold worldwide and genetic indexes had a value on an international level. The commensuration of animals' genetic worth was no longer local, but international. Under this scientific regime of calculation, a national and international market for animal indexed semen became possible.

\section{Limits and contestation of the scientific regime of calculation}

The scientific modes of evaluating animals' genetic values could not be opposed to and did not replace the "eye of the breeder" in the qualification processes of all animal populations and breeder communities. Breeders' associations kept organising animal competitions where aesthetic criteria were as important as genetic indexes. In the cattle industry, for meat production. farmers used less performance recording and genetic indexes since the evaluation of the animals could rely more easily on visual observation. In the 1970 s, the scientific regime of calculation and the national system of genetic eval-

\footnotetext{
57. J. Podolny and M. Hill-Popper, "Hedonic and transcendent conceptions of value", Industrial and Corporate Change,
vol. $13, \mathrm{n}^{\circ} 1$, February 2004, p. 91-116.

5. Ibid.
}

uation started to be criticise tists themselves and by $b$ tions, mainly for local ar They all pointed to the risk domestic biodiversity, as th was too expensive to be in the French breeds. Only th terms of population size c this system ${ }^{59}$. Later, this s regime of calculation was as preserving some dom even if not all the local br from it. many of them did Aubrac, the Manech Tarentaise. etc. $)^{60}$.

Analysing animals' qu cific cases such as the $M$ breed, in Basque Country. tions of scientific evaluati tion of economic value geneticists from the INRA nicians cooperated to ap to improving the three used in this industry. Pyrénées, some of the far indexed semen or geneti indexed breeding anima breeding programme. T] ewes that were "too prod ers considered a limit of milk/year) were not able environment of such a where summer grazing $\mathrm{C}$ is a traditional practice. also distrusted genetic in a relevant value to anim their own practices. T farms participating in gramme, constituting selection. were not reps the practices and produ

59 B. Bibé and B. Vissac, p. 46-51; A. Audiot, Races (6) P.-B. Joly and B. Hervien. Futuribles, $\mathrm{n}^{\circ} 292,2 \times 03, \mathrm{p}$. Conseil économiuue, social 61 J. Dewey, "Sone question 
of the exchanged imals to the creicial insemination is indexed semen. rket: whereas the $n$ governed by the s known for their g high-value aniy and Marya Hillendent conception entific regime of es" are the referand no longer the oduced the animal pper would call a value $\left.^{58}\right)$. Genetic isemination also ige of the market be sold worldwide value on an interensuration of anilonger local, but cientific regime of international marnen became possi-

\section{ation of the} f calculation

of evaluating aninot be opposed to ye of the breeder" sses of all animal er communities. ot organising aniaesthetic criteria tic indexes. In the roduction, farmers ording and genetic on of the animals visual observation. regime of calcula$\mathrm{m}$ of genetic eval-

and Corporate Change, uation started to be criticised, both by scientists themselves and by breeders' associations, mainly for local and small breeds. They all pointed to the risk of a decrease in domestic biodiversity, as the national system was too expensive to be implemented in all the French breeds. Only the largest ones in terms of population size could benefit from this system ${ }^{59}$. Later, this scientific, national regime of calculation was finally recognised as preserving some domestic biodiversity: even if not all the local breeds could benefit from it, many of them did (for example, the Aubrac, the Manech Black Face, the Tarentaise, etc. ${ }^{60}$.

Analysing animals' qualification in specific cases such as the Manech Black Face breed, in Basque Country, reveals the limitations of scientific evaluation in the construction of economic values. In this region, geneticists from the INRA, farmers and technicians cooperated to apply genetic models to improving the three local sheep breeds used in this industry. In the Western Pyrénées, some of the farmers refused to buy indexed semen or genetically improved and indexed breeding animals produced by the breeding programme. They considered that ewes that were "too productive" (some farmers considered a limit of 120 or 130 litres of milk/year) were not able to thrive in the harsh environment of such a mountainous area, where summer grazing on mountain pastures is a traditional practice. Some of the farmers also distrusted genetic indexes' ability to give a relevant value to animals that could fit with their own practices. They considered that farms participating in the breeding programme, constituting the environment of selection, were not representative enough of the practices and production environment of the rest of the farms. More specifically, they argued that, due to the constraints of using the breeding techniques that were compulsory in the breeding program, farms that did not practice summer grazing were favoured compared to other farms. Evaluation, prizing and pricing processes ${ }^{61}$ were closely linked. The price of breeding animals and indexed semen was defined not only theoretically by the value given through genetic indexes, but also by the level of trust that users could have in this evaluation. In the Western Pyrénées, the highest prices were found to be paid for animals with the lowest assurance, according to scientific criteria, of the animals' genetic value. In other words, the most expensive animals on the market were breeding animals sold by farmers outside of the breeding program. Those rams had no "scientific" or "objective" genetic information, but did have high aesthetic value for the farmers. Some of them considered that the animals from the breeding programme failed to meet the aesthetic standard of the breed: their horns did not have the right shape; the animals were not thin or elegant enough, etc. They also argued that their animals could not be considered only as machines to produce milk, but also as living beings that they had to enjoy working with.

Some farmers' reputation of producing animals with high aesthetic standards also participated in raising prices. Other criteria were put forward as reasons why farmers sometimes preferred buying non-evaluated animals from other farmers, rather than evaluated animals from the breeding company. For example, they sometimes preferred to buy animals from farmers who had practices similar to their own (usually, summer grazing practices), rather than from the breeding

${ }^{59}$ B. Bibé and B. Vissac, « Gènes en péril : d'importants risques pour notre économie ", Élevage bovin, $\mathrm{n}^{\circ} 15,1975$, p. resources and sustainable livelihoods", Ecological economics, vol. 45, n³ 3, July 2003, p. 331-339.

resources and sustainable livelihoods", Ecological economics, vol. 45, n 3, July 2003 , pes recherches en génomique ", ${ }^{60}$ P.-B. Joly and B. Hervieu, «La marchandisation de Conseil économique, social et environnemental, 2009, p. 156.

${ }^{61}$ J. Dewey, "Some questions about value", The Journal of Philosophy, vol. 41, n 17, August 1944, p. 449-455. 
company where animals were kept in the barn and fed intensively all year long. The animals from the breeding company would indeed be more likely to die when taken to mountain pastures.

These few examples reveal how the scientific order is not the only one to govern the valuation process of animals' genetic worth in this industry. Aesthetic order, social relations between buyers and sellers, and environmental conditions still play a key role in valuation processes, despite the historical process of implementing a national and scientific regime of calculation.

\section{CONCLUSION}

This paper has highlighted how animals: commensuration based on scientific reasoning came long before genetic theories were put forward. It has detailed the emergence of a scientific regime of calculation in the realm of animal genetics, revealing how tools. devices and specific organisations have been designed to allow for the calculation of the future performance of animals, based on the recording of the past ${ }^{62}$. But our analysis also reveals the political role of scientists and the government in organising a national valuation system, without which the scientific regime of calculation could not be institu. tionalised. Empirical analysis of a case study of animal valuation in the Western Pyrénées has also shown that this valuation process, when analysing a specific situation and a local industry, is all but smooth and automatic. This case study has allowed us to identify different modes of intervention of genetic models in the animal breeding economy, and to show that the scientific order is far from being the only one to govern the valuation process of animals' genetic worth in the industry.

Further research is however needed. Recent radical changes in genetic theories and technologies for "calculating life", through the development of genomic tools and in a new political context (liberalisation of animal genetic markets), offer a great opportunity to identify how the introduction of a new technology impacts calculation processes and market forms ${ }^{63}$. Other studies have started to show how genomic selection made possible a privatisation of the calculation process of genomic indexes and the creation of new animal categories ${ }^{64}$.

The author acknowledges the financial support of INRA Métaprogramme SELGEN (projects COOPIGEN and CROSSING) and of the Region Midi-Pyrénées (projet Génom-Inno).

\footnotetext{
62 A. van den Bogaard, "Past measurement and future prediction", in M. S. Morgan and M. Morrison (eds.), Meklals as mediators, Cambridge, Cambridge Lniversity Press, 1999, p. 282-325.

63 J. Labatut, G. Allaire and F. Aggeri, « Étudier les biens communs par les changements institutionnels : régimes de propriété autour des races animales face à l'innovation génomique $»$, Revue de la résulation, $\mathrm{n}^{\circ} 14$, automne 2013.

64 G. Allaire, J. Labatut and G. Tesnière, « Complexité des communs et régimes de droits de propriété : le cas des ressources génétiques animales s, Revte d'Économie Politique, vol, 128, $\mathrm{n}^{\circ} 1$, to be published in 2018.
}

\section{GARAN}

SA N

Les ressources devrait rester Convention sur droits intellectu article examine sources génétic $d^{\prime} a c c e ̀ s$ et $d^{\prime} a p$ $d$ 'hui d'arbitrer ressources.

INTRODUCTIC

Beaucoup de économie de l'env le terme de «marc

1 P. Méral, "Le concen Sociétés, vol, $20, n^{\circ}$. ments pour services en P. Lascoumes et P. Le Presses de Sciences PC Ecosystem Services : Dimensions of Intectio vices écosystémiques Neolibéralisation de V. Boisvert, « Des litr conseryation $\approx$, Ecol 